\title{
THE CONDITIONAL OFFER OF MEMBERSHIP AS AN INSTRUMENT OF EU FOREIGN POLICY: RESHAPING EUROPE IN THE EU'S IMAGE*
}

\author{
Karen E.Smith**
}

\begin{abstract}
The European Union directed its efforts in creating stability and security in Europe towards the enlargement to the east and to the south starting from the end of the 1980s. Connected to this political effort was the offering of conditional membership in the EU, especially to the central and eastern European countries (CEES) as a means of creating a new European order in the post-Cold War era.

Conditional membership means the adopting of the political and economic reforms according to the model presented by the EU Member States. The present enlargement issue of the EU, differing from the previous enlargements, constitutes an important foreign policy goal of the Community and therefore brings an imposition upon the candidate countries to adopt specific development directions according to certain characteristics. Support is provided conditionally only to such developments and policy changes in the candidate countries. Karen E. Smith, in this study, presents an analysis of the political and economic transformations in central and eastern European countries as well as in Cyprus and Turkey in the process of candidacy and evaluates the estimated gains with respect to the foreign policy goals of the European Union.
\end{abstract}

\section{Introduction}

Since the late 1980s, the Community/Union has tried to spread stability and security eastwards, with varying degrees of success. It has been especially active in formulating a policy towards those Central and East European countries (CEECs) that were formerly members of the Warsaw Pact. The key instrument of that policy is the conditional offer of EU membership. The EU has used membership conditionality to influence the CEECs - encouraging them to

* This is a revised version of a paper presented to the Georgia Political Science Association meeting in Hilton Head, South Carolina, 25-26 February 2000.

** London School of Economics, Department of International Relations. 
undertake political and economic reforms - and thus shape the post-Cold War European order. Enlargement is expected to consolidate the economic and political transformation in Central and Eastern Europe, which will in turn enhance European security. Similar expectations arise in relation to enlargement to southern states, particularly Cyprus and Turkey. There is a strong belief within the EU that integration and interdependence among democratic states with market economies will ultimately lead to a more stable and secure Europe.

The first section analyses why and how the EU has used enlargement as a foreign policy instrument. The second section explores the advantages and disadvantages of this particular foreign policy instrument. The EU is here considered to be a 'unitary' actor, in that the emphasis is not on the internal processes of decision-making on enlargement, but on the outcomes and implications of the decisions that the EU has taken (collectively) on enlargement.

\section{Enlargement as Foreign Policy}

Back in 1989, Roy Ginsberg classified enlargement as a type of foreign policy action, which resulted specifically from the process of 'externalisation': a foreign policy option that could be executed in response to outside pressure from eligible nonmembers who want to join the club. ${ }^{1}$ Ginsberg considered all of the enlargements of the Community to be foreign policy actions. This is too broad a conception of foreign policy, in the sense of a plan of action formulated to try to fulfil specific political or security-related objectives. It is doubtful whether the first enlargement to the UK,

Ireland and Denmark, or the enlargement to Austria, Finland, and Sweden, can be considered foreign policy, in that these countries were not admitted primarily (or even secondarily) in pursuit of political or security-related objectives of the EU. But one could certainly argue that enlargement to Greece, Portugal and Spain was intended to reach political and security-related objectives, namely that of helping to consolidate the process of democratisation, and therefore was foreign policy.

More recently, the prospect of enlargement has certainly been used to try to reach political and security-related objectives, in Central and Eastern Europe and the eastern Mediterranean. Enlargement, and specifically the conditional offer of membership, is explicitly an instrument of foreign policy. ${ }^{2}$ As Christopher Hill has noted, the enlargement decisions 'can be seen as a commitment to a major new foreign policy on the part of the EU, that of changing the map of Europe to the East and to the South....[T]he aim is to extend the zone of economic prosperity and "democratic peace" as a prophylactic against war, nationalism and autocracy.13 
As communism collapsed across Central and Eastern Europe, the new. governments looked to the European Community, and then the European Union, for assistance. To a remarkable extent, the EU responded collectively to their requests (although not as generously as the CEECs hoped). Strikingly, it used conditionality to try to encourage and support the reform process: the EU offered trade concessions, association ('Europe') agreements, and aid, conditional on progress towards democracy and the market economy, and the protection of human rights. ${ }^{4}$ The success of these reforms was considered crucial for ensuring long-term stability and security in Europe, in the belief that capitalist, free-trading, democratic countries make better neighbours because they do not pose a threat to security.

The CEECs soon declared that their number one foreign policy objective was to 'rejoin Europe', which entailed joining the EU (and NATO). Many within the EU and Eastern Europe argued that the Union would have to promise that the CEECs could eventually become member states, because this would provide them with a 'reward' for continuing with reforms even as those reforms caused hardship. For some time, these voices were weaker than those urging a more cautious approach, who cited the considerable upheaval widening would cause within the EU. The widening vs. deepening debate within the EU eventually resulted in a compromise, at Copenhagen in June 1993. The European Council agreed to enlarge as part of its pledge to support the reform process, on which peace and security in Europe depended. ${ }^{5}$ It declared that those CEECs that had concluded a Europe agreement were eligible for EU membership, provided they could meet three conditions: they must have a functioning market economy with the capacity to cope with competitive pressures and market forces within the EU; they must have achieved stability of institutions guaranteeing democracy, the rule of law, human rights and respect for and protection of minorities; and they must be able to take on the obligations of EU membership including adherence to the aims of economic and political union. An additional condition specifies that the EU must be able to absorb new members and maintain the momentum of integration. The Copenhagen conditions applied only to Europe agreement signatories: Bulgaria, Czech Republic, Estonia, Hungary, Latvia, Lithuania, Poland, Romania, Slovakia, and Slovenia.

The Copenhagen conditions add to the already existing membership criteria. The basic condition for Community membership - European identity - was set out in the 1958 Rome Treaty (article 237) - 'Any European state may apply to become a member of the Community'. During the Cold War eligibility was not such a troublesome issue, as membership for states outside the Western half of the continent was unthinkable. Other West European countries were either not interested and/or were not democratic. In April 
1978, the European Council declared that 'respect for and maintenance of representative democracy and human rights in each Member State are essential elements of membership in the European Communities.' This was a clear signal to Greece, Portugal and Spain that they could become Community members if they proceeded with democratisation. The Amsterdam Treaty has since formalised the political conditions of membership, declaring that 'the Union is founded on the principles of liberty, democracy, respect for human rights and fundamental freedoms, and the rule of law, principles which are common to the Member States' (article 6). Any European state which respects these principles may apply to become a member of the Union (article 49). But the growing queue of membership applicants (including the EFTAns) as well as the relative economic and political 'under-development' of the CEECs - has made it imperative for the EU to set out additional requirements of membership, as in the Copenhagen conditions.

After the Copenhagen European Council, another condition was set, that of 'good neighbourliness'. This first cropped up in the EU's Pact for Stability, the conference held in 1994-95 to encourage the Central and East European applicants to reach bilateral and multilateral agreements guaranteeing minority rights and borders. The Central and East European countries were led to believe that failure to conclude such good-neighbourly agreements would not help their chances of joining the EU. In its Agenda 2000 report on enlargement, published in July 1997, the European Commission stated that it 'considers that, before accession, applicants should make every effort to resolve any outstanding border dispute among themselves or involving third countries. Failing this they should agree that the dispute be referred to the International Court of Justice. ${ }^{16}$ This condition was reiterated by the Helsinki European Council in December 1999: it stresses the principle of peaceful settlement of disputes in accordance with the United Nations Charter and urges candidate States to make every effort to resolve any outstanding border disputes and other related issues. Failing this they should within a reasonable time bring the dispute to the International Court of Justice. The European Council will review the situation relating to any outstanding disputes, in particular concerning the repercussions on the accession process and in order to promote their settlement through the International Court of Justice, at the latest by the end of $2004 .^{7}$

Membership conditionality has been used to try to influence internal and external developments in Central and Eastern Europe above all, less so with respect to the eastern Mediterranean. It has been used as a foreign policy instrument, as a means to get other international actors to do what they would not otherwise do. ${ }^{8}$ Specific examples of the use of membership conditionality are numerous, some of which are given in section II. But pressure derives 
particularly from the fact that the EU evaluates each membership application in terms of whether, and to what extent, the CEEC meets the Copenhagen conditions.

The European Commission in the first instance (Agenda 2000, July 1997) considered that only five CEECs were eligible to open negotiations with the EU. The Luxembourg European Council in December 1997 agreed with this assessment and the Czech Republic, Estonia, Hungary, Poland and Slovenia began negotiations in March 1998. This in and of itself increased the pressure on the remaining five CEECs to make faster progress towards meeting the conditions. The Helsinki European Council in December 1999 then agreed to open negotiations with the remaining five (see below on the inconsistencies of this decision). The justification for opening negotiations was that all five of these countries met the Copenhagen political conditions, and some came closer than others to meeting the remaining conditions. Although negotiations have been opened now with all ten CEEC candidates, the European Council has made it clear that 'in the negotiations, each candidate State will be judged on its own merits. This principle will apply both to opening of the various negotiating chapters and to the conduct of the negotiations. ${ }^{19}$ Thus, the pressure on the CEECs to meet the conditions remains high.

The case of the eastern Mediterranean, and specifically the Republic of Cyprus and Turkey, is different. In both, the same formal conditions were an issue, even though technically speaking, both applications were not subject to the Copenhagen conditions (which were formulated for those CEECs that had concluded Europe agreements). The EU evaluated the economic situation, ability to implement the acquis, human rights, and democracy. In 1994, the Corfu European Council agreed to include the Republic of Cyprus in the first round of membership negotiations, which then opened in March 1998. The Helsinki European Council in December 1999 agreed that negotiations with Turkey could open only once the political conditions had been fulfilled; the good-neighbourliness condition (as outlined above) can also be interpreted to imply that Turkey's disputes with Greece over territory as well as Cyprus must be resolved first. But as discussed in section II, the good-neighbourliness condition has not been much of an issue in the case of Cyprus, while the EU's relations with Turkey have been plagued by so many other considerations that the use of conditionality almost backfired.

Before discussing the advantages and disadvantages of using membership conditionality, it is worth a digression to analyse further the EU's behaviour. In wielding enlargement and specifically the conditional offer of membership as a foreign policy instrument, what kind of international actor is the EU? 
Here the difference between 'civilian model' and 'power bloc', two possible models of the EU's international behaviour, proposed by Christopher Hill, is illuminating..$^{10}$ Under the civilian model, the EU relies primarily on persuasion and negotiation in dealing with third countries and international issues. This is similar to Franois Duchne's vision: 'The European Community's interest as a civilian group of countries long on economic power and relatively short on armed force is as far as possible to domesticate relations between states, including those of its own members and those with states outside its frontiers. ${ }^{11}$

Power bloc behaviour entails the Union using its economic strength for political purposes, to reach its own objectives. This is more akin to what we associate traditionally with national foreign policy, only, of course, the EU would act to further 'European interests' (to the extent that they can be defined). Acting as a power bloc involves the use of both carrots (offering or granting rewards) and sticks (threatening or inflicting non-violent punishment). In other words, it involves the use of non-violent coercion, 'forcing' rather than persuading other actors to do what they would not otherwise do.

In exercising leverage by using EU membership conditionality, the EU is acting very much like a power bloc. Interestingly, however, the interests at stake are not as 'self-interested' as one might expect of a power bloc; they are a mixture of self-interest and wider concerns..$^{12}$ On the one hand, the conditions are supposed to help ensure that the EU continues to function after enlargement, both by effectively requiring that the applicant states reduce the differences between themselves and the rest of the EU, and by indicating that enlargement can proceed only if will not impede integration. This is clearly in the EU's own interest. But on the other hand, the EU's underlying objective is one associated with the civilian model: peace and security are achieved by institutionalising interdependence among democratic, capitalist states - that is, by 'domesticating' relations between states. The use of coercion by the EU with respect to membership conditionality is not easily captured by either conceptual approach.

Attention now turns to how influential the EU has been in using this foreign policy instrument. How effective is it? Has the conditional offer of EU membership worked?

\section{Evaluating the Effectiveness of Membership Conditionality}

The question of EU influence reflects a more general debate about the influence of external pressure on other actors - how much influence can outsiders have on internal processes and developments? Much of the literature on democratisation, for example, has found that outsiders have less influence on internal processes of democratisation than domestic actors. ${ }^{13}$ External influence 
can never be overwhelming - third countries may be willing but unable to meet the externally-set conditions for a wide variety of reasons, including the negative influences of their past history (underdevelopment, entrenched conservative forces, and so on).

Having said that, two requirements for the effective use of conditionality can be put forward: 1) conditionality will only be effective (especially over time) if it is applied consistently - otherwise it loses force because third states will question why they have been targeted and others not, or vice versa; 2 ) the use of conditionality will be effective only to the extent that the third country in question desires the carrot on offer or fears the stick. It should be added that the third country must also believe that the carrot and stick are credible options, that they will actually be wielded.

Clearly, the EU has been able to influence Central and East European countries' internal and external policies, although there are still limits to its influence. The CEECs appear to be very susceptible to external pressure, partly because they so desire to 'return to Europe'. In some cases, the EU's conditionality may be superfluous (as the government needed little outside pressure to undertake reforms or adapt to the EU acquis), and in fact, may even breed resentment. Yet conditionality could be influential where reforms are more contested, or where the government is not making progress in preparing for accession.

Numerous examples of the EU's pressure can be cited. The prospect of being excluded from EU membership negotiations helped to spur Hungary and Slovakia, and Hungary and Romania, to conclude good-neighbourly agreements, within the framework of the Pact for Stability. However, Hungary and Romania did not conclude their agreement during the actual negotiation stage of the Pact, but a year later. Estonia and Latvia have been successfully pressed to improve their legislation regarding ethnic Russians living in those countries. The EU has not, however, been the only international actor pressing for these changes - the OSCE High Commissioner for National Minorities and the Council of Europe have also advocated and mediated legislative reforms. The fact that the EU made it clear that respect for minority rights and solution of border conflicts are conditions for membership certainly contributed to the pressure, even if it did not prove decisive. ${ }^{14}$

In 1994 and 1995, Romania appeared to have been heading towards more nationalistic and racist politics, as extremist parties gained power. The EU indicated that these developments would not help Romania's application for membership, and from mid-1995 the Romanian government - prompted by President Ion Ilescu - changed its course: over the next year, the ruling Social 
Democrats broke with extremist parties and an agreement with Hungary was negotiated. A new reformist government took office in November 1996, and relations with the EU improved significantly. ${ }^{15}$ Given this, there was concern that excluding Romania from the first round of negotiations would send too negative a message and lead to disillusionment. Romania did express considerable dismay with the decision to exclude them from the first round of talks. While progress towards meeting the conditions has still been quite slow, Romania was eventually included in the second round of negotiations - because it was considered to have met the political criteria. This would also prevent the isolation of a country already suffering from the instability and war in south-eastern Europe.

Even more pressure was put on Slovakia during the period of the Meciar government - the EU delivered demarches and issued numerous warnings that Slovakia must meet democratic norms before it could join the EU. In 1997, the Commission and European Council agreed that Slovakia should not be included in the first round of membership negotiations, primarily on the basis of political criteria. ${ }^{16}$ Yet the Meciar government remained in power and did not alter its behaviour in response to the EU's pressure. In October 1998, however, Slovak voters chose a new coalition government, which was united by a desire to join the EU and NATO. The new government has made some progress by engaging in political reforms - and was rewarded by the Helsinki European Council's decision to open negotiations with it - but is still quite weak, and Meciar remains a powerful domestic force.

Most recently, Bulgaria and Romania were given specific conditions to be met before the Helsinki European Council. Bulgaria had to decide on acceptable closure dates for a nuclear power plant and show evidence of making progress on economic reforms. Romania had to take action to reform its child care institutions and also show evidence of making progress on economic reforms. Both countries were judged to have met these conditions by December 1999.

On the whole, the use of membership conditionality has 'worked', in that all of the CEECs are trying to meet the EU's conditions. Several problems have become apparent with this approach - most notably the risk that differentiating among the CEECs will alienate those that are further behind. The way the EU has handled this risk is to assure all of the CEECs that EU membership is a real possibility: they will join if they meet the conditions. The latest step in this direction has been to open negotiations with all of the CEECs, even though some of them may be negotiating for many years before they accede to the EU. By doing so, 
the EU has glossed over some of the difficulties the CEECs are having in meeting the conditions, which could ultimately lead to questions about the extent to which the EU has been consistent in its use of conditionality. But it is unlikely that countries will join the EU before they are, for the most part, ready to do so. A further problem that arises for the EU is whether it can handle so many negotiations at once - those further ahead in terms of meeting the conditions may feel that the pace has slowed down.

Still, membership conditionality seems to be doing the job that it was intended to do. It has by and large been applied consistently, the CEECs strongly desire to join the EU and hence are willing to try to meet the conditions, and the prospect of membership is still considered highly likely by all of the CEECs. As an instrument of EU foreign policy, it can be judged to have been pretty effective.

The same positive assessment cannot be put forward wholeheartedly with respect to the EU's treatment of the membership applications from Cyprus and Turkey. In the case of Cyprus, the good-neighbourliness 'condition' has been avoided; in the case of Turkey, the signals sent have been so inconsistent that the EU's leverage stemming from membership conditionality has been severely reduced, although it might recently have recovered strength.

The Republic of Cyprus applied for membership in 1990. In June 1993, the Commission's opinion on the application was largely positive - not only did the Republic of Cyprus meet the necessary political and economic criteria, but the Commission was also convinced that Cyprus' accession would 'increase security and prosperity' and help 'bring the two communities closer together'. It stated that 'Cyprus' integration with the Community implies a peaceful, balanced and lasting settlement of the Cyprus question'. The Commission felt that a positive signal should be sent that Cyprus is eligible 'and that as soon as the prospect of a settlement is surer, the Community is ready to start the process with Cyprus that should eventually lead to its accession. ${ }^{17}$ In June 1994, the Corfu European Council agreed that Cyprus should be involved in the next enlargement. A year later, the Cannes European Council declared that negotiations with Cyprus should be opened six months after the conclusion of the 1996 intergovernmental conference. Formal membership talks with Cyprus opened in March 1998. The prospect of a settlement, however, seemed no surer than it had been in 1993.

The Union has repeatedly stated that it supports a just and lasting settlement of the Cyprus question, and that the prospect of accession will provide an incentive for this. But it has not stated that accession will be blocked should 
no settlement be reached, and it has continued to negotiate with the Republic of Cyprus although no representatives of the Turkish Cypriot community are included in the delegation (the Republic of Cyprus is effectively negotiating the entry of the entire island). The Helsinki European Council stated that 'a political settlement will facilitate the accession of Cyprus to the European Union.' But 'if no settlement has been reached by the completion of accession negotiations, the Council's decision on accession will be made without [this] being a precondition. ${ }^{18}$ Conditionality has not been applied consistently here, as good-neighbourliness has been ignored. The EU seems to be hoping that the carrot will be enough to spark a solution. The EU has declined to use its leverage openly and explicitly, never threatening to use the stick with respect to the Republic of Cyprus. The Greek position has by and large prevented the Union from doing so, although the other member states also appear to be reluctant. Instead, the EU has put pressure on Turkey to contribute to a resolution of the issue, and on the Turkish Cypriots to join the negotiating delegation. ${ }^{19}$ How successful this approach will be depends also on the state of the EU's relations with Turkey.

Yet inconsistency is obvious in the case of Turkey. In 1987, it applied for membership; in 1989, the Commission's opinion concluded that it would not be appropriate or useful to open accession negotiations with Turkey. The Commission, Council and European Parliament have persistently raised problems regarding Turkey's human rights and democracy situation, and the EP has used these issues to block aid and the customs union. But the attempt to use membership conditionality (to act as a power bloc) failed because the Union did not credibly hold out the tastiest carrot. Turkey has watched the EFTAns and the CEECs jump the queue, while various European politicians cited cultural and religious factors for its exclusion, and Greece placed obstacles in the way of closer relations. Turkey had every reason to suspect that it would never become a member of the club even if it had a fully functioning democracy and exemplary human rights record. This doubt seemed to be confirmed when the December 1997 European Council placed Turkey in its own separate category of applicant states, although it confirmed its eligibility for membership. This prompted it to suspend its relations with the EU. The EU's leverage over Turkey diminished.

More recently, of course, relations have improved remarkably. The Helsinki European Council classified Turkey as an official candidate (entailing inclusion in the pre-accession strategy and conclusion of an Accession Partnership), although it made it clear that membership negotiations would only be opened once the political conditions have been met. Consequently, the EU's influence seems to have increased. It is still not clear how willing Turkey is to undertake the necessary reforms (such as outlawing the death penalty). Turkish elites, 
as Lauren McLaren notes, do not put as much emphasis on key political and foreign policy reforms as the EU does ${ }^{20}$ Of course if outsiders are seen to be responsible for highly unpopular policies, then the outsiders could be rejected. The extent to which Turkey must undertake political, economic and even constitutional reform - as well as contribute to a resolution of the Cypriot issue - to meet the EU's membership conditions could spark a backlash and rejection of the EU (a risk in the CEECs as well). But for now, it appears that the EU has gained influence, by indicating that membership is actually a possibility.

This apparent success of membership conditionality in the case of the CEECs in particular has been part of the reason why enlargement is an attractive policy option for other countries as well. The conditional offer of membership is such a powerful instrument that the EU could wield influence in areas where the West's influence has been marginal or even negative: south-eastern Europe and the former Soviet Union. The issue of further enlargement also arises because of the open-ended nature of the Amsterdam Treaty: membership is in principle open to countries beyond those currently in the queue, if they meet the conditions of article 49. But is the EU now obliged to take in all states that meet the conditions?

In April 1999, the German presidency put forward a proposal for a Stability Pact in south-eastern Europe, which urged that the EU make a 'clear and repeated commitment' that 'the countries in the region have a prospect of acceding, even if the time of accession can not yet be determined.' This was necessary because 'the prospect of EU membership is a key incentive to reform. This is the only way to keep the south-eastern European countries on the stabilization track in the long term. ${ }^{21}$ The rest of the EU was not so bold: the CFSP Common Position launching the Stability Pact only mentions that the $\mathrm{EU}$ 'will draw the region closer to the perspective of full integration of these countries into its structures... with a perspective of EU membership on the basis of the Amsterdam Treaty and once the Copenhagen criteria have been met. ${ }^{122}$ But how realistic is this perspective?

If the EU cannot absorb those states currently in the queue, or if it cannot absorb those on the outside, then the influence of membership conditionality will diminish: why try to meet the conditions if you're not certain you'll be able to join? After all, implementation of the instrument of enlargement entails fundamental reform of the Union - the external policy must be matched by internal change. This may be exceedingly difficult; it may even be impossible to preserve the current character of the EU as it enlarges ever more. But if the EU cannot make good on article 49, then conditionality itself could lose its force.

Most European states will accept nothing less than full EU membership for them, the 'return to Europe' means joining the EU. But EU membership is 
not a panacea for all the ills of the European continent - though it seems increasingly as though this is believed within the EU as well as outside it. Furthermore, if EU membership is considered the defining characteristic of 'European-ness', then states on the outside will feel that much more marginalised. ${ }^{23}$ There seems to be a trade-off: using membership conditionality could work now, but the EU's influence could eventually diminish - either because it cannot actually fulfil the promises to enlarge or because doing so would risk its effectiveness and even its very existence. Reshaping all of Europe in the EU's image may prove to be more of a challenge than the EU can handle.

\section{Endnotes}

${ }^{1}$ Roy Ginsberg, Foreign Policy Actions of the European Community: The Politics of Scale (Boulder: Lynne Rienner, 1989), chapter 7. Other responses include association agreements, trade and aid agreements, development aid, diplomatic ties, and so on.

${ }^{2}$ Several observers have argued, however, that enlargement must be seen more holistically, not just as external policy. Lykke Friis and Anna Murphy argued that enlargement has significant internal consequences, particularly for the internal development of the Union, which thus affects decision-making. See their article, "The European Union and Central and Eastern Europe: Governance and Boundaries', Journal of Common Market Studies, vol. 37, no. 2, June 1999.

${ }^{3}$ Christopher Hill, 'The Geo-Political Implications of Enlargement', in Jan Zeilonka, ed., The Borders of Europe (forthcoming, 2001).

${ }^{4}$ Conditionality entails the linking, by a state or international organisation (in this case, the $\mathrm{EU}$ ) of perceived benefits to another state to the fulfilment of certain conditions. See Olav Stokke, 'Aid and Political Conditionality: Core Issues and State of the Art', in Olav Stokke, ed., Aid and Political Conditionality (London: Frank Cass, 1995).

${ }^{5}$ European Council, Copenhagen, 21-23 June 1993, Conclusions of the Presidency, SN/180/93, 13.

${ }^{6}$ European Commission, 'Agenda 2000: For a Stronger and Wider Union', EU Bulletin, Supplement 5/97,51.

${ }^{7}$ Helsinki European Council, 10-11 December 1999, Presidency Conclusions, paragraph 4.

${ }^{8}$ See the definition in David Baldwin, Economic Statecraft (Princeton: Princeton University Press, 1985), 8-9.

${ }^{9}$ Helsinki European Council, 10-11 December 1999, Presidency Conclusions, paragraph 11. 
${ }^{10}$ Christopher Hill, 'European Foreign Policy: Power Bloc, Civilian Model - or Flop?', in Reinhardt Rummel, ed., The Evolution of an International Actor: Western Europe's New Assertiveness (Boulder: Westview, 1990).

11 Fransois Duchne, 'The European Community and the Uncertainties of Interdependence', in Max Kohnstamm and Wolfgang Hager, eds, A Nation Writ Large? Foreign-Policy Problems Before the European Community (London: Macmillan, 1973), 19-20.

${ }^{12}$ A perhaps tenuous comparison could be made here with US hegemony in the postWorld War II period: it created multilateral regimes to promote an 'embedded' liberal economic order, mixing self-interest and wider concerns. See John Gerard Ruggie, 'International Regimes, Transactions and Change: Embedded Liberalism in the Postwar Economic Order', International Organization, vol. 36, no. 2, Spring 1982, and 'Multilateralism: The Anatomy of an Institution', International Organization, vol. 46, no. 3, Summer 1992.

${ }^{13}$ See, for example, Geoffrey Pridham, ed., Encouraging Democracy: The International Context of Regime Transition in Southern Europe (Leicester: Leicester University Press, 1991).

${ }^{14}$ See Sven Arnswald, 'The Politics of Integrating the Baltic States into the EU: Phases and Instruments', in Mathias Jopp and Sven Arnswald, eds, The European Union and the Baltic States: Visions. Interests and Strategies for the Baltic Sea Region (Helsinki: The Finnish Institute of International Affairs and Bonn: Institute fur Europaische Politik, 1998).

${ }^{15}$ I recount these developments in Karen E. Smith, The Making of EU Foreign Policy: The Case of Eastern Europe (London: Macmillan, 1998), 142-3.

${ }^{16}$ Ibid., 141-2.

${ }^{17}$ Cited in Graham Avery and Fraser Cameron, The Enlargement of the European Union (Sheffield: Sheffield Academic Press, 1998), 95-6.

${ }^{18}$ Presidency Conclusions, paragraph 9(b).

${ }^{19}$ For an overview of the EU's approach to the Cyprus problem, and a discussion of four possible scenarios for the future, see Neill Nugent, 'EU Enlargement and the "Cyprus Problem"', Journal of Common Market Studies, vol. 38, no. 1, March 2000.

${ }^{20}$ Lauren M. McLaren, 'Turkey's Eventual Membership of the EU: Turkish Elite Perspectives on the Issue', Journal of Common Market Studies, vol. 38, no. 1, March 2000.

${ }^{21}$ German Presidency, 'A Stability Pact for South-Eastern Europe', paragraph IV.1, 12 April 1999; http://www.bundesregierung.de/english/01/0103/3810/index.html. 
${ }^{22}$ Common Position of 17 May 1999 Concerning the Launching of the Stability Pact of the EU on South-Eastern Europe, Document no. 99/087, European Foreign Policy Bulletin online (published by the European University Institute, Florence).

${ }^{23}$ On the perceived negative implications of EU enlargement for two outsiders, see Margot Light, Stephen White and John Lowenhardt, 'A Wider Europe: The View from Moscow and Kyiv', International Affairs, vol. 76, no. 1, 2000. 